\title{
Recurrent abdominal pain: a psychogenic disorder?
}

\author{
P J McGRATH, J T GOODMAN, P FIRESTONE, R SHIPMAN, AND S PETERS \\ Children's Hospital of Eastern Ontario and University of Ottawa, Ottawa, Canada
}

SUMMARY A controlled study of 30 children with recurrent abdominal pain and 30 pain free children failed to show any statistically significant differences between the groups on a variety of psychological variables thought to be associated with psychogenicity. A psychogenic basis has often been assumed as the cause in diagnosis of recurrent abdominal pain when clinical examination and laboratory tests show no organic or medical reason. We emphasise that establishing a psychogenic cause is only indicated where there is positive evidence for psychological factors such as family or school stress, extreme personality characteristics, or modelling of family pain behaviour.

Increasing attention to the psychosocial, emotional, and family aspects of paediatric medicine has led to more comprehensive care of children and their families. Many conclusions in published reports about psychosocial, emotional, and family factors in paediatrics have, however, been based on clinical impression rather than verifiable scientific data. Recurrent abdominal pain of no known organic cause is a disorder occurring in approximately $10 \%$ of children. ${ }^{1}$ Lactose malabsorption has recently been suggested as a cause, but studies investigating this have been contradictory. ${ }^{2}{ }^{3}$ The dominant view is that recurrent abdominal pain is a response to the stress of pervasive family or school problems in predisposed children. ${ }^{4}$ The psychological predisposition is thought to be a personality that is anxious, socially unskilled, self conscious, and perfectionist. ${ }^{4}$ In addition, the parents of children with recurrent abdominal pain have been reported to have pain themselves and to model pain behaviour for their children. ${ }^{5}$

Two major problems over the role of psychological factors in recurrent abdominal pain have plagued published reports-most studies lack appropriate control groups and, without exception, clinical impressions rather than objective, reliable, and valid measurements have been used as evidence for the role of psychological factors.

\section{Method}

Thirteen boys and 17 girls referred by their family doctor to the gastroenterology service of the Children's Hospital of Eastern Ontario were matched for age and sex with children attending other outpatient clinics for minor physical problems such as sprains or upper respiratory infections. The mean age of the children in the study was 11 years 3 months and the range was 6 years 5 months -16 years 5 months. Each of the children in the recurrent abdominal pain group met the criteria outlined by Apley, ${ }^{4}$ which included at least three attacks of pain occurring over a period longer than 3 months, with no known organic cause, and severe enough to affect the child's participation in his normal activities. They underwent a thorough physical examination and rectal examination including immediate microscopy of stools for ova and parasites, with no positive results. Laboratory investigations included blood count and in most cases urine analysis and culture. All test results were within normal limits. In addition, all the children with recurrent abdominal pain were followed up for at least 18 months and none developed an organic pathology that would account for their pain.

A structured interview was conducted with each child and at least one parent to provide comparison information between children with recurrent abdominal pain and control children with no history of abdominal pain. The Quay-Peterson behaviour checklist ${ }^{6}$ was completed independently by each of the child's parents and the child's teacher. The Poznanski depression scale ${ }^{7}$ was completed by the interviewer and the Birleson self report scale ${ }^{8}$ was completed by the child. Each parent independently completed the Locke-Wallace marital adjustment scale. ${ }^{9}$ Sociodemographic measures were taken for each child's family along with a measure of the amount of life stress each child had experienced, and a family history of pain. A complete medical and pain history was also determined for each child. In addition, 25 of the children with recurrent abdominal 
pain and 19 control children were tested for lactose malabsorption using the lactose breath hydrogen test described by Barr. ${ }^{2}$

The personality problem subscale of the QuayPeterson behaviour problem checklist was selected as a measure of personality in this study because the 14 items in the subscale reflect the description that is usually given in published reports of the child with recurrent abdominal pain. ${ }^{4}$ These items include: does not know how to have fun; behaves like an adult; self conscious; shy; lacks self confidence; feelings easily hurt; chronic general fearfulness; inability to relax; and socially reserved. The remaining personality measures, the inadequacyimmaturity subscale and the Poznanski and Birleson scales were included because they cover a wide range of personality factors that have-on occasion -been noted in children with recurrent abdominal pain. The inadequacy-immaturity subscale of the Quay-Peterson behaviour problem checklist is an 8 item scale including: short attention span; excessive day dreaming; sluggishness; and lethargy. The Poznanski scale measures depression as assessed by interview and the Birleson scale is a self report measure of depression.

\section{Results}

Children with recurrent abdominal pain and their families were compared with pain free children and their families. Mean scores of continuous variables were compared using Student's $t$ test. Dichotomous data were analysed using the normal curve test for significance of the difference between two proportions. Because a large number of comparisons were made in order to reduce experimental error, tabled alpha was set at 0.01 for each test. Failure to account for multiple comparisons could lead to reporting a number of differences that were caused by chance alone.

Table 1 presents the comparisons between recurrent abdominal pain children and control children on stress factors. The mothers and fathers of both groups had similar scores on the LockeWallace marital adjustment scale. In fact the only group that showed any trend towards marital dissatisfaction was the fathers of the control children.
Table 2 Family pain history of children with recurrent abdominal pain and in control children

\begin{tabular}{|c|c|c|c|c|}
\hline & \multicolumn{2}{|c|}{$\begin{array}{l}\text { Recurrent abdominal } \\
\text { pain children }\end{array}$} & \multicolumn{2}{|c|}{$\begin{array}{l}\text { Control } \\
\text { children }\end{array}$} \\
\hline & No & $(\%)$ & No & $(\%)$ \\
\hline Parents with pain now & $13 / 53$ & (24) & $15 / 51$ & (29) \\
\hline $\begin{array}{l}\text { Children whose siblings have } \\
\text { stomach pain now }\end{array}$ & $5 / 30$ & (16) & $6 / 30$ & (20) \\
\hline $\begin{array}{l}\text { Children whose siblings have } \\
\text { other pain now }\end{array}$ & $5 / 30$ & (16) & $12 / 30$ & (40) \\
\hline $\begin{array}{l}\text { Children who had stomach pain } \\
\text { preschool }\end{array}$ & $18 / 30$ & (60) & $3 / 30$ & (10) \\
\hline $\begin{array}{l}\text { Children who had pain, other } \\
\text { than stomach pain preschool }\end{array}$ & $12 / 30$ & (40) & $4 / 30$ & (13) \\
\hline
\end{tabular}

Table 3 Personality of children with recurrent abdominal pain and of control children. (Sample size in brackets)

\begin{tabular}{|c|c|c|c|}
\hline Measure & Rated by & $\begin{array}{l}\text { Recurrent } \\
\text { abdominal } \\
\text { pain } \\
\text { children }\end{array}$ & $\begin{array}{l}\text { Control } \\
\text { children }\end{array}$ \\
\hline $\begin{array}{l}\text { Quay-Peterson personality } \\
\text { problems subscale }\end{array}$ & $\begin{array}{l}\text { Mother } \\
\text { Father } \\
\text { Teacher }\end{array}$ & $\begin{array}{l}2 \cdot 3(30) \\
1 \cdot 5(24) \\
2 \cdot 7(22)\end{array}$ & $\begin{array}{l}1 \cdot 8(30) \\
1 \cdot 6(23) \\
1 \cdot 6(23)\end{array}$ \\
\hline $\begin{array}{l}\text { Quay-Peterson } \\
\text { inadequacy-immaturity } \\
\text { subscale }\end{array}$ & $\begin{array}{l}\text { Mother } \\
\text { Father } \\
\text { Teacher }\end{array}$ & $\begin{array}{l}0.6(30) \\
0 \cdot 5(24) \\
1 \cdot 1(22)\end{array}$ & $\begin{array}{l}0.2(29) \\
0.2(23) \\
0 \cdot 7(23)\end{array}$ \\
\hline Poznanski depression scale & Interviewer & $16 \cdot 7(30)$ & $15 \cdot 6(30)$ \\
\hline Birleson depression scale & Child & $8 \cdot 0(30)$ & $6 \cdot 8(30)$ \\
\hline
\end{tabular}

Similarly, both groups were equally likely to have both parents living in the home $(83 \%$ for children in the pain group and $87 \%$ for the control children). Children with pain and controls came from families of similar income and had experienced a similar amount of life change in the preceding year.

The pain histories (Table 2) of the two groups showed that the children with abdominal pain were more likely to have had stomach aches $(60 \%)$ and other pain $(40 \%)$ in their preschool years than control children $(10 \%$ and $13 \%$, respectively). On the other hand, parents and siblings of children with pain did not have any more pain than the parents and siblings of control children.

Table 3 presents data on the personality of

Table 1 Stress factors in 30 children with recurrent abdominal pain and in 30 control children

\begin{tabular}{|c|c|c|c|c|c|c|c|c|c|c|}
\hline & $\begin{array}{l}\text { Locke-I } \\
\text { adjustm } \\
\text { mothers } \\
\text { Score }\end{array}$ & $\begin{array}{l}\text { Vallace marital } \\
\text { ent scale: } \\
(\mathrm{No})\end{array}$ & $\begin{array}{l}\text { Locke- } \\
\text { adjustm } \\
\text { fathers } \\
\text { Score }\end{array}$ & $\begin{array}{l}\text { Vallace marital } \\
\text { ent scale: } \\
(\mathrm{No})\end{array}$ & $\begin{array}{l}\text { Bot } \\
\text { No }\end{array}$ & $\begin{array}{l}h \text { parents at home } \\
(\%)\end{array}$ & $\begin{array}{l}\text { Total fam } \\
\text { income } \\
\text { Amount }\end{array}$ & $\begin{array}{l}\text { iily } \\
\qquad(\mathrm{No})\end{array}$ & $\begin{array}{l}\text { Child's } \\
\text { events } \\
\text { Score }\end{array}$ & $\begin{array}{l}\text { life } \\
(\mathrm{No})\end{array}$ \\
\hline $\begin{array}{l}\text { Recurrent abdominal pain children } \\
\text { Control children }\end{array}$ & $\begin{array}{l}115 \cdot 4 \\
110 \cdot 0\end{array}$ & $\begin{array}{l}(25) \\
(25)\end{array}$ & $\begin{array}{l}116 \cdot 2 \\
100 \cdot 5\end{array}$ & $\begin{array}{l}(24) \\
(19)\end{array}$ & $\begin{array}{l}25 \\
27\end{array}$ & $\begin{array}{l}(83) \\
(87)\end{array}$ & $\begin{array}{l}\$ 30114 \\
\$ 33116\end{array}$ & $\begin{array}{l}(29) \\
(28)\end{array}$ & $\begin{array}{l}136 \cdot 5 \\
129 \cdot 3\end{array}$ & $\begin{array}{l}(30) \\
(30)\end{array}$ \\
\hline
\end{tabular}


children with recurrent abdominal pain and control children. There are no statistically significant differences between the two groups. There were, however, consistent, small non-significant differences in the direction of more depression and immaturity in the recurrent abdominal pain children.

Breath hydrogen testing showed that 6 children (24\%) with recurrent abdominal pain had evidence of lactose malabsorption. Four control children ( $21 \%$ of those tested) also showed evidence of lactose malabsorption. A second analysis of the psychological data excluding these children yielded results identical to the initial analysis.

\section{Discussion}

The finding of no differences between children who have recurrent abdominal pain and those who do not, does not mean that the null hypothesis of no difference is proved. Several factors may have led to our failure to find differences. First of all, a selection bias may well have been operating. The children with pain had been referred by their family doctors to the gastroenterology department: children with psychologically related recurrent abdominal pain, such as school phobia, would have been referred elsewhere and would not therefore be included in this study. A second possibility is that the measures were simply not sensitive enough to detect the psychological problems that are related to recurrent abdominal pain. The findings do not, however, support the widespread assumption that recurrent abdominal pain, for which no medical cause can be found, is psychogenic. It may well be-as Barr ${ }^{11}$ has suggested-that most children with recurrent abdominal pain suffer from a benign symptom that is indicative of neither organic nor psychological pathology.
This research was funded by the Ontario Ministry of Health (DM 507) and by the Children's Hospital of Eastern Ontario Foundation. Dr McGrath is supported by a Career Scientist Award of the Ontario Ministry of Health. The authors wish to thank Dave Streiner, of McMaster University, Hamilton, and June Cunningham of the Children's Hospital of Eastern Ontario for their assistance. Breath hydrogen samples were analysed by Dr Ron Barr of Montreal Children's Hospital.

\section{References}

1 Apley J, Naish N. Recurrent abdominal pains: a field survey of 1,000 school children. Arch Dis Child 1958;33: 165-70.

2 Barr RG, Levine MD, Watkins JB. Recurrent abdominal pain of childhood due to lactose intolerance: a prospective study. $N$ Engl J Med 1979;300:1449-52.

${ }^{3}$ Lebenthal E. Recurrent abdominal pain in childhood. Am J Dis Child 1980;134:347-8.

4 Apley J. The child with abdominal pains. 2nd edition. Oxford: Blackwell Scientific Publications, 1975.

5 Christensen MF, Mortensen O. Long term prognosis in children with recurrent abdominal pain. Arch Dis Child $1975 ; 50: 110-4$.

6 Quay HC, Peterson DR. Manual for the behavior problem checklist. Denver: City Publisher, 1979.

7 Poznanski EO, Cook SC, Carrol BJ. A depression rating scale for children. Pediatrics 1979;64:442-50.

8 Birleson P. A self rating scale for depressive disorder. Thesis: University of Edinburgh, 1978.

${ }^{9}$ Locke HJ, Wallace KM. Short marital adjustment and prediction tests: their reliability and validity. Marriage and family living $1959 ; 21: 251-5$.

10 Coddington RD. The significance of life events as etiologic factors in the diseases of children. II a study of normal population. J Psychosom Res 1972;16:205-13.

11 Barr RG, Feuerstein M. Recurrent abdominal pain syndrome. How appropriate are our basic clinical assumptions? In: PJ McGrath, P Firestone, eds. Pediatric and adolescent behavioural medicine: issues in treatment. New York: Springer, 1983.

Correspondence to Dr McGrath, Children's Hospital of Eastern Ontario, 401 Smyth Road, Ottawa, Ontario K1H 8L1.

Received 4 July 1983 